\title{
Determining the source of transmission of SARS-CoV-2 infection in a healthcare worker
}

Nasia Safdar ${ }^{1}$, Gage K. Moreno ${ }^{2}$, Katarina M. Braun ${ }^{3}$, Thomas C. Friedrich ${ }^{3,4}$, David H. O'Connor ${ }^{2,4}$

Affiliations

${ }^{1}$ University of Wisconsin School of Medicine and Public Health, Madison, WI 53705 and the William S. Middleton Memorial Veterans Hospital

${ }^{2}$ Department of Pathology and Laboratory Medicine, University of Wisconsin-Madison, Madison, WI, 53711

${ }^{3}$ Department of Pathobiological Sciences, University of Wisconsin-Madison, Madison, WI, 53711

${ }^{4}$ Wisconsin National Primate Research Center, University of Wisconsin-Madison, Madison, WI, 53711

Acknowledgement: We thank Fauzia Osman for creating Figure 1.

Funding: NS is supported by NIH Award: 1DP2Al144244-01. GKM is supported by NSF Award: HRD-1612530. KMB was supported by NIH F30 Award: Al145182-01A1. 
medRxiv preprint doi: https://doi.org/10.1101/2020.04.27.20077016; this version posted May 1, 2020. The copyright holder for this preprint (which was not certified by peer review) is the author/funder, who has granted medRxiv a license to display the preprint in perpetuity. It is made available under a CC-BY-NC-ND 4.0 International license .

Background: Healthcare workers (HCWs) are at the frontlines of the COVID-19 pandemic and are at risk of exposure to SARS-CoV-2 infection from their interactions with patients and in the community $(1,2)$. Limited availability of recommended personal protective equipment (PPE), in particular N95 respirators, has fueled concerns about whether HCWs are adequately protected from exposure while caring for patients. Understanding the source of SARS-CoV-2 infection in a HCW - the community or the healthcare system - is critical for understanding the effectiveness of hospital infection control and PPE practices. In Dane County, Wisconsin, community prevalence of SARS-CoV-2 is relatively low (cumulative prevalence of $~ 0.06 \%$ - positive cases / total population in Dane county as of April 17). Although SARS-CoV-2 infections in HCWs are often presumed to be acquired during the course of patient care, there are few reports unambiguously identifying the source of acquisition.

Objective: To determine the source of transmission of SARS-CoV-2 in a healthcare worker.

Methods and Findings: Here we report a case of SARS-CoV-2 in a HCW at UW Hospital who performed direct patient care for two non-critically ill patients with confirmed SARS-CoV-2 infections (patient 1 and patient 2). While caring for these patients, the HCW wore a barrier mask, face shield, gowns and gloves. Four days after providing care for these patients, the HCW began experiencing headache, fever, and sore throat. A nasopharyngeal (NP) swab was obtained and tested positive for SARS-CoV-2 viral RNA. To establish the most likely source of infection, we interviewed the HCW's family member (HCW-F), who had developed a febrile illness eight days before onset of symptoms in the HCW, but was not tested initially due to limited testing availability. We obtained a NP swab from HCW-F which also tested positive for SARS-CoV-2. Figure 1 shows 
medRxiv preprint doi: https://doi.org/10.1101/2020.04.27.20077016; this version posted May 1, 2020. The copyright holder for this preprint (which was not certified by peer review) is the author/funder, who has granted medRxiv a license to display the preprint in perpetuity.

It is made available under a CC-BY-NC-ND 4.0 International license.

the timeline of events in the four individuals (HCW, HCW-F, Patient 1, and Patient 2) evaluated in this report.

We sequenced viral RNA isolated from NP swab obtained from the two hospitalized patients the HCW treated, the HCW, and the HCW's family member. We compared consensus SARS-CoV-2 sequences from these four individuals to determine whether the HCW likely acquired infection in a healthcare setting or the community.

Samples from all four individuals were prepared for sequencing using the ARTIC protocol (3) and were sequenced on an Oxford Nanopore GridION device. Consensus sequences were derived using a modified version of the ARTIC bioinformatics protocol (4) that analyzes data once 100,000 reads are obtained from each sample (analysis pipelines are available on GitHub) (5). Figure 2 shows single nucleotide variants (SNVs) that differ at the consensus level between each sample and the original Wuhan reference sequence (Genbank: MN908947.3). The HCW sequence is identical to the HCW-F sequence and distinct from both hospitalized patients (Patient 1 and 2).

Discussion: While we cannot formally exclude the possibility that the HCW was infected by another asymptomatic, untested hospitalized patient, the identical viral sequences found in the HCW and HCW's family member provide strong circumstantial evidence for chain of transmission occurring outside of the hospital. Sequencing the HCW's virus facilitated rapid identification of the likely source of infection - community transmission. This offers reassurance to HCWs currently treating COVID-19 patients that appropriate PPE protects against hospital-acquired SARS-CoV-2 infection. Conversely, demonstrating nosocomial acquisition by sequencing would have provided an impetus for revisiting infection control strategies. Based on these results, viral sequencing of SARS-CoV-2 
medRxiv preprint doi: https://doi.org/10.1101/2020.04.27.20077016; this version posted May 1, 2020. The copyright holder for this preprint (which was not certified by peer review) is the author/funder, who has granted medRxiv a license to display the preprint in perpetuity. It is made available under a CC-BY-NC-ND 4.0 International license.

from HCWs and known contacts both within and outside of patient care settings should be considered an essential part of a comprehensive strategy to protect the health of HCWs and other frontline responders.

Ethics: The University of Wisconsin-Madison Institutional Review Board deemed this study quality improvement, rather than research, and so declined to subject this study to full review. 
medRxiv preprint doi: https://doi.org/10.1101/2020.04.27.20077016; this version posted May 1, 2020. The copyright holder for this preprint (which was not certified by peer review) is the author/funder, who has granted medRxiv a license to display the preprint in perpetuity. It is made available under a CC-BY-NC-ND 4.0 International license.

\section{References}

1. Characteristics of Health Care Personnel with COVID-19 - United States, February 12 April 9, 2020. MMWR Morb Mortal Wkly Rep 2020;69:477-481.

2. Zhan M, Qin Y, Xue X, Zhu S. Death from Covid-19 of 23 Health Care Workers in China. N Engl J Med. 2020 Apr 15. doi: 10.1056/NEJMc2005696.

3. https://artic.network/ncov-2019/ncov2019-bioinformatics-sop.html

4. https://www.protocols.io/view/ncov-2019-sequencing-protocol-bbmuik6w

5. https://github.com/katarinabraun/SARS-CoV2_sequencing/tree/master/Pipelines_to_process_data/Nanopore_pipeline_ARTIC 
medRxiv preprint doi: https://doi.org/10.1101/2020.04.27.20077016; this version posted May 1, 2020. The copyright holder for this preprint (which was not certified by peer review) is the author/funder, who has granted medRxiv a license to display the preprint in perpetuity. It is made available under a CC-BY-NC-ND 4.0 International license .

Figure 1. Timeline of infection, contact and testing in the four individuals.
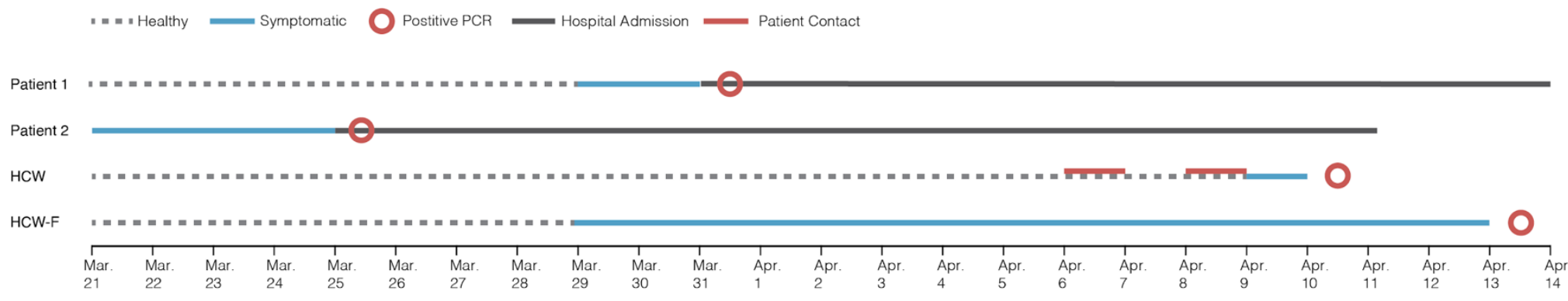
medRxiv preprint doi: https://doi.org/10.1101/2020.04.27.20077016; this version posted May 1, 2020. The copyright holder for this preprint (which was not certified by peer review) is the author/funder, who has granted medRxiv a license to display the preprint in perpetuity.

It is made available under a CC-BY-NC-ND 4.0 International license .

Figure 2. SARS-CoV-2 consensus-level single nucleotide variants. The top alignment image depicts the SARS-CoV-2 genome for all individuals evaluated in this report and highlights SNVs identified relative to the original SARS-CoV-2 Wuhan reference (Genbank: MN908947.3). The table contains additional information about each of these SNVs. A2a clade-defining mutations are shaded light-blue. A dot "." indicates identity with reference.



\begin{tabular}{|c|c|c|c|c|c|c|c|}
\hline Position & Location & Reference & HCW & HCW-F & Patient 1 & Patient 2 & Annotation \\
\hline 241 & 3' UTR & C & $\mathrm{T}$ & $\mathrm{T}$ & $\mathrm{T}$ & $\mathrm{T}$ & \\
\hline 1,059 & ORF1ab & C & . & . & $\mathrm{T}$ & . & T265। \\
\hline 3,307 & ORF1ab & C & $\mathrm{T}$ & $\mathrm{T}$ & $T$ & $\mathrm{~T}$ & Synonymous \\
\hline 3,871 & ORF1ab & G & . & . & . & $\mathrm{T}$ & K1202N \\
\hline 9,053 & ORF1ab & G & . & . & . & $\mathrm{T}$ & V2930L \\
\hline 11,417 & ORF1ab & G & $\mathrm{T}$ & $\mathrm{T}$ & . & . & V3718F \\
\hline 14,073 & ORF1ab & $\mathrm{T}$ & C & C & . & . & Synonymous \\
\hline 14,408 & ORF1ab & C & $\mathrm{T}$ & $\mathrm{T}$ & $\mathrm{T}$ & $\mathrm{T}$ & P4715L \\
\hline 23,403 & S & A & G & G & G & G & D614G \\
\hline 23,947 & $S$ & A & G & G & . & . & Synonymous \\
\hline 25,563 & ORF3a & G & . & . & $\mathrm{T}$ & . & $\mathrm{Q} 57 \mathrm{H}$ \\
\hline 27,348 & ORF6a & $T$ & G & G & . & . & Y49* \\
\hline 29,008 & N & $\mathrm{T}$ & . & . & . & C & Synonymous \\
\hline
\end{tabular}





21 
2. $\mathrm{HCW}$

3. $\mathrm{HCW}-\mathrm{F}$

4. Patient 1

5. Patient 2

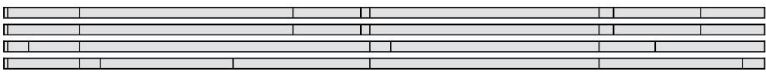

\begin{tabular}{|c|c|c|c|c|c|c|c|}
\hline Position & Location & Reference & HCW & HCW-F & Patient 1 & Patient 2 & Annotation \\
\hline 241 & $3^{\prime}$ UTR & G & $\mathrm{T}$ & $\mathrm{T}$ & $\mathrm{T}$ & $\mathrm{T}$ & \\
\hline 1,059 & ORF1ab & C & . & . & $\mathrm{T}$ & . & T265I \\
\hline 3,307 & ORF1ab & C & $\mathrm{T}$ & $\mathrm{T}$ & $\mathrm{T}$ & $\mathrm{T}$ & Synonymous \\
\hline 3,871 & ORF1ab & G & . & . & . & $\mathrm{T}$ & $\mathrm{K} 1202 \mathrm{~N}$ \\
\hline 9,053 & ORF1ab & G & . & . & . & $\mathrm{T}$ & V/2930L \\
\hline 11,417 & ORF1ab & $\mathrm{G}$ & $\mathrm{T}$ & $\mathrm{T}$ & . & . & V/3718F \\
\hline 14,073 & ORF1ab & $\mathrm{T}$ & $\mathrm{C}$ & $\mathrm{C}$ & . & . & Synonymous \\
\hline 14,408 & ORF1ab & G & $\mathrm{T}$ & $\mathrm{T}$ & $\mathrm{T}$ & $\mathrm{T}$ & P4715L \\
\hline 23,403 & $\mathrm{~S}$ & A & $G$ & G & $\mathrm{G}$ & $\mathrm{G}$ & D614G \\
\hline 23,947 & $S$ & A & $G$ & G & . & . & Synonymous \\
\hline 25,563 & ORF3a & G & . & . & $\mathrm{T}$ & . & $\mathrm{Q} 57 \mathrm{H}$ \\
\hline 27.348 & ORF6a & $\mathrm{T}$ & $G$ & G & . & . & $Y 49^{*}$ \\
\hline 29.008 & $N$ & $\mathrm{~T}$ & . & . & . & C & Synonymous \\
\hline
\end{tabular}

